\title{
Cytotoxicity Evaluation of Ammonia-Modified Graphene Oxide Particles in Lung Cancer Cells and Embryonic Stem Cells
}

\author{
Milena Keremidarska-Markova $\left(\mathbb{D},{ }^{1,2}\right.$ Kamelia Hristova-Panusheva ${ }^{(D)},{ }^{1}$ Tonya Andreeva ${ }^{(D)}{ }^{1}$ \\ Giorgio Speranza $\mathbb{D}^{3},{ }^{3}$ Dayong Wang, ${ }^{4}$ and Natalia Krasteva $\mathbb{(}^{1}$ \\ ${ }^{1}$ Institute of Biophysics and Biomedical Engineering, Bulgarian Academy of Sciences, Sofia 1113, Bulgaria \\ ${ }^{2}$ Faculty of Biology, Sofia University "St. Kliment Ohridski”, Sofia 1164, Bulgaria \\ ${ }^{3}$ University of Trento, Trento 38122, Italy \\ ${ }^{4}$ Medical School in Southeast University, Nanjing 210096, China
}

Correspondence should be addressed to Natalia Krasteva; nataly@bio21.bas.bg

Received 13 August 2018; Accepted 19 September 2018; Published 3 October 2018

Academic Editor: Fajun Zhang

Copyright (C) 2018 Milena Keremidarska-Markova et al. This is an open access article distributed under the Creative Commons Attribution License, which permits unrestricted use, distribution, and reproduction in any medium, provided the original work is properly cited.

\begin{abstract}
Potential toxicity of graphene oxide $(\mathrm{GO})$ is a subject of increasing research interest in the recent years. Here, we have evaluated the cytotoxicity of ammonia-modified $\mathrm{GO}\left(\mathrm{GO}-\mathrm{NH}_{2}\right)$ and pristine $\mathrm{GO}$ particles in human lung cancer cells, A549 and embryonic stem cells, Lep3 exposed to different particles concentrations $(0.1,1,10,20$, and $50 \mu \mathrm{g} / \mathrm{ml})$ for different times $(24$ and $48 \mathrm{~h})$. Compared with $\mathrm{GO}, \mathrm{GO}-\mathrm{NH}_{2}$ particles possessed smaller size, positive surface charge and higher thickness. An increased propensity to aggregation in cell cultures was also found for GO- $\mathrm{NH}_{2}$ particles. Cytotoxicity evaluation revealed that $\mathrm{GO}-\mathrm{NH}_{2}$ particles are more toxic than pristine GO. Applied at concentrations of 10,20 and $50 \mu \mathrm{g} / \mathrm{ml}$ for $24 \mathrm{~h}$ they affect significantly cell morphology of viable embryonic stem cells whereas human lung cancer A549 cells seem to be relatively more resistant to short-time exposure. After $48 \mathrm{~h}$ exposure however cell proliferation of A549 cells was strongly suppressed in a dose-dependent manner while the proliferation ability of embryonic stem cells was not affected. These results suggested that both GO particles exert different degree of cytotoxicity which is time, dose and cell dependent. In general, ammonia-modified GO particles are more toxic than the pristine GO which should be taken into account for future biomedical applications.
\end{abstract}

\section{Introduction}

Graphene oxide (GO) is a material with unique properties suitable for diverse applications in electronics, telecommunications, energy, and biomedicine $[1,2]$. One of these applications, as a drug carrier for cancer therapy, is of particular interest. GO offers many advantages for cancer therapy. The presence of reactive functional groups at the basal plane and edges of GO nanosheets creates an opportunity to covalently modify the particles for use in targeted drug delivery, while the abundance of localized $\pi$-electrons at the nanosheets surface enables $\pi-\pi$ interactions with aromatic antitumor drugs $[3,4]$. The drug loading capacity of GO is substantially greater than other conventional drug carriers, such as polymeric micelle, hydrogel microparticles and liposomes, approximately $200 \%$ by its weight and this is the first drug carrier achieving over $100 \%$ loading [5]. GO is able to unload the drugs under acidic and basic conditions because of the rupture of the hydrogen bonds between the $-\mathrm{COOH}$ and the $-\mathrm{OH}$ groups of $\mathrm{GO}$ and the $-\mathrm{OH}$ and the $-\mathrm{NH}_{2}$ groups of the drug [6]. In addition, GO may induce the generation of reactive oxygen species (ROS) in target cancer cells, which is considered as one of the most important nanotoxicity mechanisms of GO [7-9]. However, during cancer therapy the surrounding normal healthy cells or rapidly dividing healthy cells should not be damaged [10]. Thus, the toxicity of GO could hamper its application for medical purposes. In order to reduce the toxicity of GO and improve its in vivo biocompatibility, many factors affecting the toxicity profile of GO have to be considered. 
Toxicity of GO is largely dependent on intrinsic physicochemical properties including lateral size, thickness, number of layers, surface properties, and methods of the synthesis, in addition to the dose, time of exposure, cell type, and administration method [11-14]. Among these factors, surface properties (e.g., functional groups, charge, carbon/oxygen ratio, and hydrophobicity) are crucial in determining the nature of the interaction between GO and biomolecules [15]. Previous studies revealed that GO was highly thrombogenic and could induce aggregation of platelets [16, 17], whereas amine-modified graphene did not induce such an effect on platelets [18].

Surface modification is a commonly used approach to improve the biocompatibility and cytotoxicity of GO for safer biomedical applications [19]. PEGylation, for example, reduces nonspecific protein adsorption to biological membranes thus preventing flocculation and opsonization and subsequent complement activation [20-23]. Besides PEGylation, other chemical functionalizations of nanoparticles should be explored for the development of GO materials with improved biocompatibility, less immune response, and longer blood circulation [24]. Some of these modifications however, such as GO-COOH and GO-PEI, have been found to exhibit some degree of toxicity on $\mathrm{T}$ lymphocytes [25]. Therefore, reduction of GO cytotoxicity can be done only with proper functionalization.

Amination of biomaterials used as substratum for cell attachment has already been shown to have positive effect on adhesion, migration, and functions of normal cells [26]. For example, Lee et al. reported for improved adhesion and growth of hamster ovary cells on aminated polyethylene polymeric surfaces [27]. Another study showed that the higher density of amine groups on glass coverslips increased the adhesion, migration, and differentiation of rat neural stem cells [28]. Amornsudthiwat et al. confirmed the positive effect of $\mathrm{NH}_{2}$ groups on mouse fibroblast cell adhesion using nitrogen plasma treated silk fibroin surfaces [29]. Moreover some authors have reported that $\mathrm{NH}_{2}$-modified carbon nanomaterials showed improved compatibility with normal cells and tissues. Lee et al. demonstrated that pretreatment of rats with amine-modified carbon nanotubes could prevent neuronal death and enhance the recovery of neural functions after brain stroke [30]. These data suggest that the presence of $\mathrm{NH}_{2}$-groups on the nanomaterial's surface could help avoiding some of the side effects on normal cells during chemotherapy; however the effects of amine-functionalized (NPs) on human cancer and normal cells have to be studied thoroughly.

Therefore the object of the present study was to evaluate the cytotoxic effect of ammonia-modified GO NPs and pristine GO on human alveolar carcinoma cell line A549 and embryonic stem cells Lep3, treated with different particle concentration for 24 and $48 \mathrm{~h}$. A549 cells were used as a cell model of lung cancer, because lung cancer is considered as one of the leading malignant causes for mortality worldwide due to the high levels of air pollution and the great amount of smokers in the developing countries [31]. Moreover many biodistribution studies have shown that GO accumulates predominantly in the lungs [32]. Lep3 cells were used as a model of normal, rapidly dividing healthy cells. The existing lack of information about the effect of amine-enriched GO NPs on cancer cells and embryonic stem cells as well as the conflicting information about the cytotoxicity of GO particles makes the present work an important step toward future biomedical strategies including graphene-based nanomaterials.

\section{Materials and Methods}

\subsection{Particles and Particle Characterization}

2.1.1. Particles. Graphene oxide (C1576, Graphenea, Spain) and ammonia-modified graphene oxide (791520, SigmaAldrich, Germany) are commercially available products, purchased as water suspensions with concentration $4 \mathrm{mg} / \mathrm{ml}$ and $1 \mathrm{mg} / \mathrm{ml}$, respectively.

For in vitro exposures, particle suspensions were prepared as stock solutions of $1 \mathrm{mg} / \mathrm{ml}$ in distilled water and sonicated in an ultrasonic water bath $(50 \mathrm{~Hz}, \mathrm{UM}-2$, Unitra-Unima, Olsztyn, Poland) for 1 hour. The final concentrations of NPs $(0.1,1,10,20$, and $50 \mu \mathrm{g} / \mathrm{ml}$, respectively) were achieved by adding the NPs from stock solution directly into the culture medium.

\subsubsection{Particle Characterization}

X-Ray Photoemission Spectroscopy (XPS). The elemental composition of the nanoparticles was analyzed by X-ray photoemission spectroscopy (XPS). The XPS measurements were carried out using an Axis DLD Ultra instrument (Kratos-Manchester, UK). The wide spectra were acquired at $160 \mathrm{eV}$ pass energy. High resolution core line spectra were performed by setting the analyzer pass energy at 20 $\mathrm{eV}$ pass energy and the final energy resolution was $\sim 0.3 \mathrm{eV}$. Fit was performed using Gaussian components and Shirley background subtraction, with a homemade software based on the R platform (https://www.r-project.org/).

Dynamic Light Scattering (DLS). The particles size distribution and zeta potential were measured by Dynamic light scattering (DLS) technique using Zetatrac instrument (S3500; Microtrac, Largo, FL). The particles size was estimated from the distribution of velocity of the Brownian motion of GO and GO-NH$H_{2}$ nanoparticles when suspended in water [33].

Atomic Force Microscopy (AFM). AFM imaging was performed on Innova Atomic Force Microscope (Bruker Inc.) in tapping mode in air, using standard silicon nitride (Si3N4) probe tips (tip radius $<10 \mathrm{~nm}$ ). Samples were scanned with rate $0.5 \mathrm{~Hz}$ at 5 different locations all over the surface exploring areas of $10 \times 10 \mu \mathrm{m}$. The images $(512 \times 512$ pixels $)$ were captured in height and deflection modes and presented with a simple first-order flattening.

2.2. Cells and Cell Culture. Cell toxicity was evaluated on human alveolar cancer A549 cells, obtained from American Type Culture Collection (ATCC ${ }^{\circledR}$ CCL-185 ${ }^{\mathrm{TM}}$ ) and human embryonic stem Lep3 cells, obtained from the Laboratory of Cell Cultures, National Centre of Infectious and Parasitic Diseases, Sofia, Bulgaria. The cells were grown as monolayer 
cultures in DMEM medium, supplemented with $10 \%$ fetal bovine serum, $100 \mathrm{U}$ ml-1 penicillin, and $100 \mu \mathrm{g}$ ml-1 streptomycin. The cultures were maintained at $37^{\circ} \mathrm{C}$ in a humidified $\mathrm{CO}_{2}$ incubator. For routine passages adherent cells were detached using a mixture of $0.05 \%$ trypsin and $0.02 \%$ EDTA. The experiments were performed during the exponential phase of cell growth. For cytotoxicity experiments the cells were seeded on sterile cover glasses with a diameter of 12 $\mathrm{mm}$ at a density of $2 \times 10^{4}$ cells/well in 24 -well plate and incubated for 24 hours. On the next day the medium was replaced with fresh one and NPs with different concentrations were added to the cells. After another $24 \mathrm{~h}$ of incubation the cells were processed according to the experiments protocol. Control cells were processed as tested samples in the absence of nanoparticles.

2.3. Phase-Contrast and Fluorescent Microscopy. Phasecontrast and fluorescent microscopy were used to evaluate NPs aggregation and alterations in cell morphology after 24 hours exposure to NPs. Phase-contrast micrographs were taken at magnification $10 \mathrm{x}$ with an inverted microscope Axiovert 25 (Carl Zeiss, Germany), equipped with a digital camera. For fluorescent visualization of the morphology of viable cells the samples were stained for 2 min with 0,001 $\%$ fluorescein diacetate (FDA) (Sigma, Germany) dissolved in acetone. After multiple rinsing with PBS fluorescent micrographs were taken at magnification 10x. Further, the fluorescent micrographs were analyzed using the Image J software to obtain the number of attached cells and the average cell spreading area of A549 cells after one day exposure to the nanoparticles.

2.4. Cell Counting Kit-8 Assay. Cell Counting Kit-8 (CCK-8, Sigma-Aldrih Co.) is a simple colorimetric assay for the determination of cell viability in cell proliferation and cytotoxicity assays. It is based on the reduction of Dojindo's highly watersoluble tetrazolium salt, WST- 8 in cells to give an orangecolor formazan dye, which is soluble in the cell culture media. The amount of the formazan dye, generated by the activities of dehydrogenases in cells, is directly proportional to the number of living cells. The CCK- 8 was performed as described previously [34]. Briefly, the cells were transferred into a new 24-well plate and washed with PBS and then a mixture of fresh culture medium and the CCK-8 reagent in ratio 10:1 was added to each sample. After 4 hours incubation at $37^{\circ} \mathrm{C}$ at dark the amount of the coloured product of the reaction was measured spectrophotometrically at wavelength $\lambda=450 \mathrm{~nm}$.

2.5. Statistical Analysis. All experiments were carried out in triplicates and the presented results are average. The error bars indicate standard deviations. The experimental data were analyzed with Student's T test. Statistical significance was accepted at a level of $\mathrm{p}<0.05$.

\section{Results}

3.1. Characterization of $\mathrm{GO}$ and $\mathrm{GO}-\mathrm{NH}_{2}$ Particles. The elemental composition of the nanoparticles is shown in Figure 1. As can be seen in Figure 1(a), the C1s XPS spectrum of GO reveals four components corresponding to different functional groups: C-C $(284.7 \mathrm{eV})$ of the sp2 carbons in the basal plane of the graphene sheets, $\mathrm{C}-\mathrm{O}(286.2 \mathrm{eV})$, $\mathrm{C}=\mathrm{O}(287.8 \mathrm{eV})$, and $\mathrm{O}-\mathrm{C}=\mathrm{O}(289.1 \mathrm{eV})$ [35]. In $\mathrm{GO}-\mathrm{NH}_{2}$ (Figure 1(c)), the same oxygen functional groups remain, but the peak intensities are much weaker than those in $\mathrm{GO}$, which means that the oxygen content in $\mathrm{GO}-\mathrm{NH}_{2}$ decreases after ammonia-modification. Elemental analysis also shows that $\mathrm{C}: \mathrm{O}$ ration in pristine $\mathrm{GO}$ is $2: 1(66.36 \%$ and $33.64 \%$, respectively) whereas in $\mathrm{GO}-\mathrm{NH}_{2} \mathrm{C}: \mathrm{O}$ ration is ca. 3:1 (70.12 $\%$ and $25.64 \%$, resp.). The oxygen content in $\mathrm{GO}-\mathrm{NH}_{2}$ is 8 $\%$ lower than in $\mathrm{GO}$, demonstrating a partial reduction of GO during the functionalization process. Elemental analysis indicated a nitrogen content of ca. $3.47 \%$ in $\mathrm{GO}-\mathrm{NH}_{2}$, while in the pristine GO it is $0-1 \%$ according to the data sheet. All this indicates both the deoxygenation of GO and the incorporation of nitrogen in the functionalized graphene oxides.

Two peaks for N1s were registered in GO-NH 2 . The N1s peak at $397.8 \mathrm{eV}$ is attributed to the nitrogen in $\mathrm{C}(\mathrm{O}) \mathrm{N}$, while the nitrogen in $-\mathrm{NH}_{2}$ is observed as the peak at $400.3 \mathrm{eV}$ [36] (Figure 1(e)). The comparison of respective percentages of these two kinds of nitrogen in $\mathrm{GO}-\mathrm{NH}_{2}$ revealed the bonding state of the nitrogen in the GO structure. The nitrogen content of the $\mathrm{C}(\mathrm{O}) \mathrm{N}$ bonds is higher than that in $-\mathrm{NH}_{2}$ which indicates that the majority of the nitrogen is covalently attached to the GO surface [37].

Topology of aminated GO NPs was examined by AFM and the corresponding AFM images of nonsonicated and sonicated GO- $\mathrm{NH}_{2}$ NPs deposited on mica substrate are shown in Figures 2(a) and 2(b). Nonsonicated GO- $\mathrm{NH}_{2}$ flakes show irregular shape and lateral dimensions of few microns (Figures 2(a) and 2(c)). The thickness within one particle varies between that of GO-NH 2 monolayer (1-2 nm) and bilayer (3-4 nm). Sonication provokes lateral fragmentation of the particles whereat irregular particles with length $100-200 \mathrm{~nm}$ detach from the aminated GO-flakes (Figures 2(b) and 2(d)). However the thickness of the disconnected particles remains the same.

DLS measurements of size distribution demonstrated that the pristine GO particles consist of two fractions with quite different sizes. $9.7 \%$ of GO particles had size of $250 \pm 68 \mathrm{~nm}$ as can be concluded from the first registered peak (Figure 3, black line) while the most of GO particles had significantly larger size, about $1.5 \pm 0.7 \mu \mathrm{m}$ as seen from the second peak. Only a single peak was detected in $\mathrm{GO}-\mathrm{NH}_{2}$ indicating that the highest percent of the particles (about $87 \%$ ) was in the nanoscale range with size $560 \pm 300 \mathrm{~nm}$.

Zeta potentials of GO and $\mathrm{GO}-\mathrm{NH}_{2}$ particles measured in aqueous solutions revealed the general potential change from negative values for the $\mathrm{GO}(-24,5 \pm 0.4 \mathrm{mV})$ to positive for GO-NH $\mathrm{N}_{2} \mathrm{NPs}(38.5 \pm 2.8 \mathrm{mV})$ (Table 1). This reversal was expectable because of the positively charge of amino groups. Such zeta potential changes have already been reported after amine modification of mesoporous silica nanoparticles [38].

\subsection{Cytotoxicity}

3.2.1. Short-Term Cytotoxicity. To observe morphological changes in the cells upon exposure phase-contrast and 


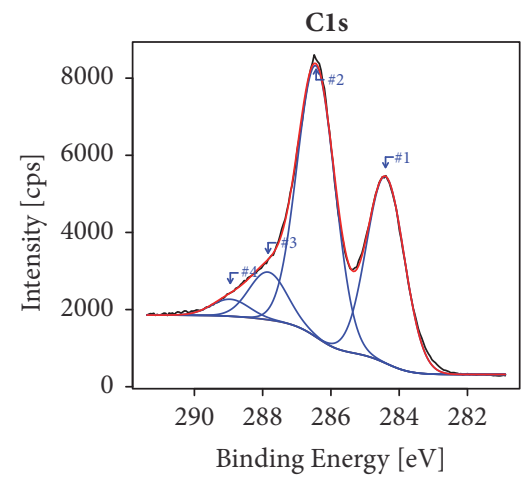

(a)

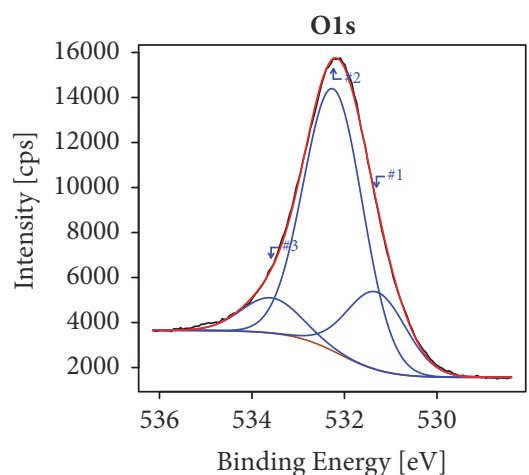

(b)

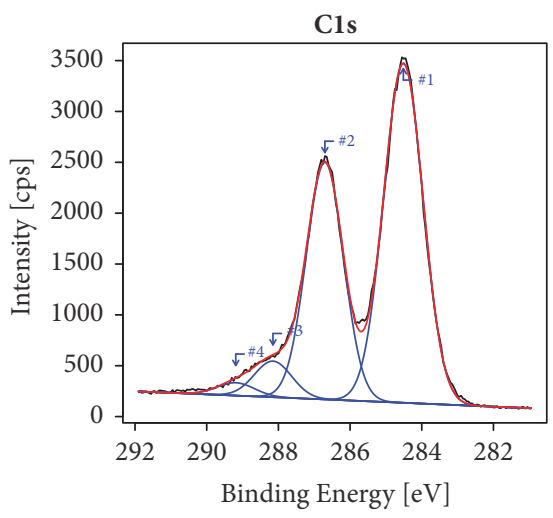

(c)

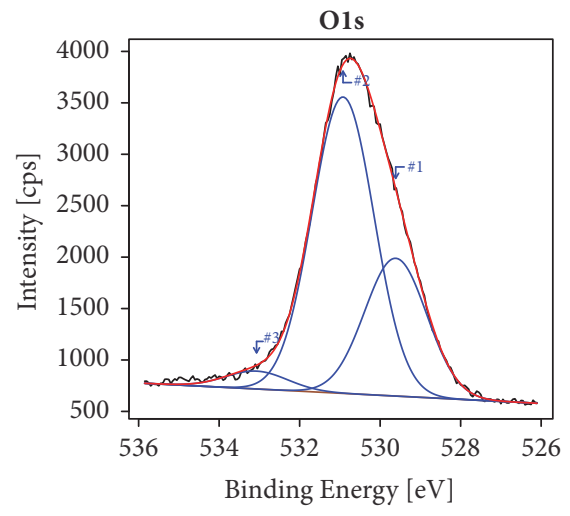

(d)

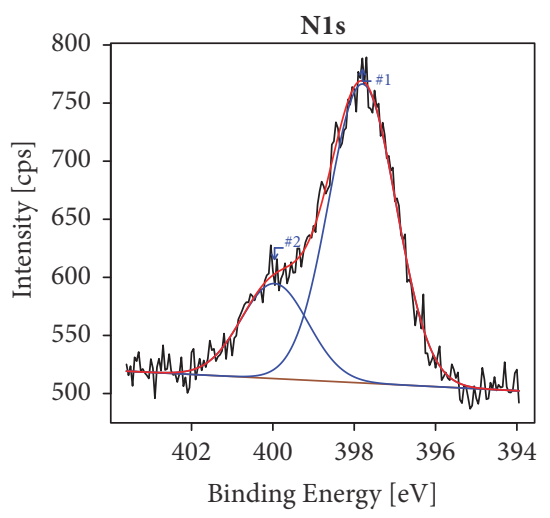

(e)

FIgure 1: Chemical components on the nanoparticles surface. (a) Carbon core line and (b) oxygen core line in GO; (c) carbon core line, (d) oxygen core line, and (e) nitrogen in $\mathrm{GO}-\mathrm{NH}_{2}$.

TABLE 1: Zeta potential of the pristine GO and GO- $\mathrm{NH}_{2}$ nanoparticles.

\begin{tabular}{lc}
\hline Nanoparticles & Zeta potential \\
\hline $\mathrm{GO}$ & $-24,5 \pm 0,4 \mathrm{mV}$ \\
$\mathrm{GO}-\mathrm{NH}_{2}$ & $38,5 \pm 2,8 \mathrm{mV}$ \\
\hline
\end{tabular}

fluorescent microscopy were used. Representative phasecontrast micrographs of A549 cells, exposed for $24 \mathrm{~h}$ to NPs (Figure 4), show that both types of GO particles, with and without ammonia modification, tend to aggregate into cell culture which influences their effective size and may affect their induced cytotoxicity. The aggregation of pristine GO particles was weaker than of aminated GO and it was observed only at the highest concentrations of 20 and 50 $\mu \mathrm{g} / \mathrm{ml}$ (Figure 4, higher panel). Aggregation of GO-NH particles was much more pronounced even at the lowest concentration of $0.1 \mu \mathrm{g} / \mathrm{ml}$ (Figure 4, lower panel). Such aggregation or agglomeration was also observed in nontumor Lep3 cells under their exposure to GO and GO-NH particles (data not shown), suggesting that aggregation of GO-particles is not dependent on the cell type but mainly on the particles type. Many types of NPs have been reported to form aggregates in physiological solutions [39] including carbon-based nanoparticles [34]. GO- $\mathrm{NH}_{2}$ aggregates were clearly visible in the cell culture media because the larger aggregates cannot pass across the cell membrane due to their large size and they remain in cells surrounding. GO and GO-NH$H_{2}$ particles did not induce shrinkage, necrosis, or apoptosis of the cells as can be concluded from overall cell morphology of A549 cells. In general, based on analysis of phase contrast pictures, the morphology of A549 cells was not affected from the type and concentrations of particles. The larger clusters of NPs however could cause mechanical damage of the cells resulting in detachment of cells from the substrate, cell loss, and decreased cell viability.

Cell viability assessed by FDA staining confirmed the conclusions made from phase-contrast pictures that morphology of viable A549 cells did not alter significantly after $24 \mathrm{~h}$ exposure to pristine and aminated GO NPs (Figure 5). Only at the highest concentrations of $\mathrm{GO}-\mathrm{NH}_{2}$ and pristine GO particles (20 and $50 \mu \mathrm{g} / \mathrm{ml}$ ) an increased number of large, nondividing cells were detected suggesting a weak cytotoxic effect. Inside some of the larger cells were observed particles and particles aggregates as pointed with arrows on Figure 5 indicating that some of NPs can pass through the cellular membrane.

Quantitative evaluation of cell viability of A549 cells made by determination of cell number and average spreading area demonstrated a minimal cytotoxicity which has been observed upon exposure to both types of nanoparticles but even then only at high concentrations. Ammonia-modified particles with concentrations of 10,20 , and $50 \mu \mathrm{g} / \mathrm{ml}$ and 


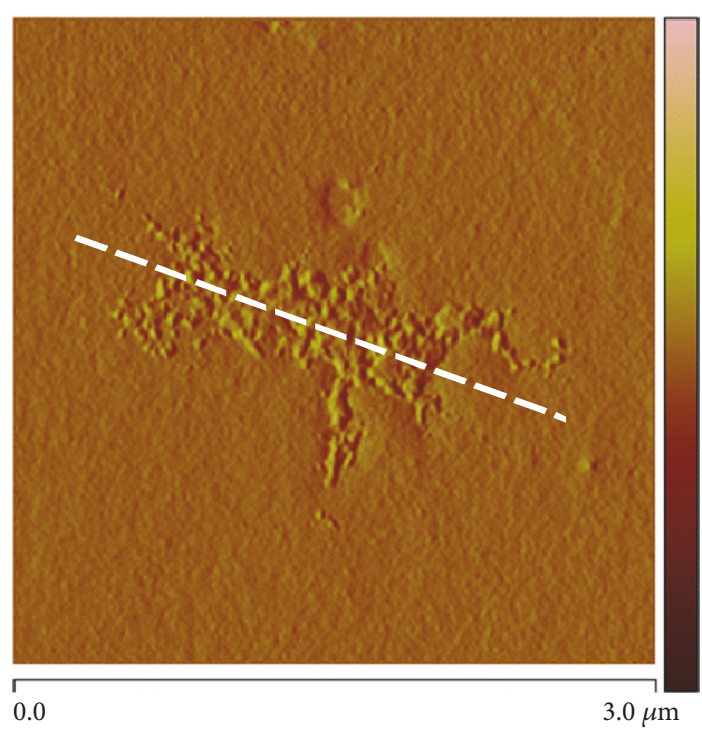

(a)

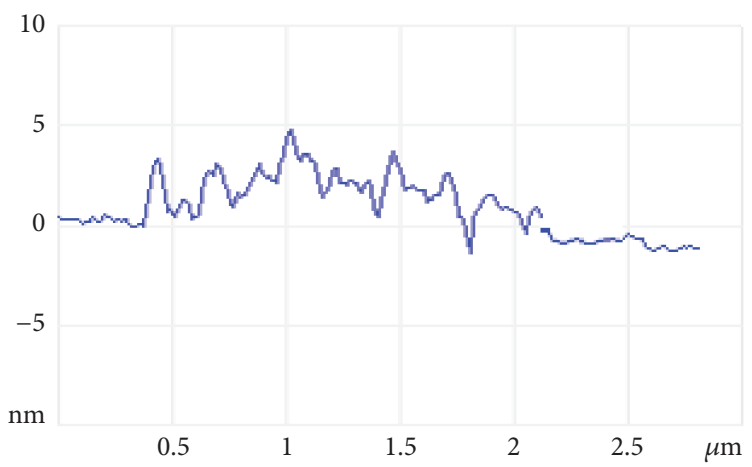

(c)

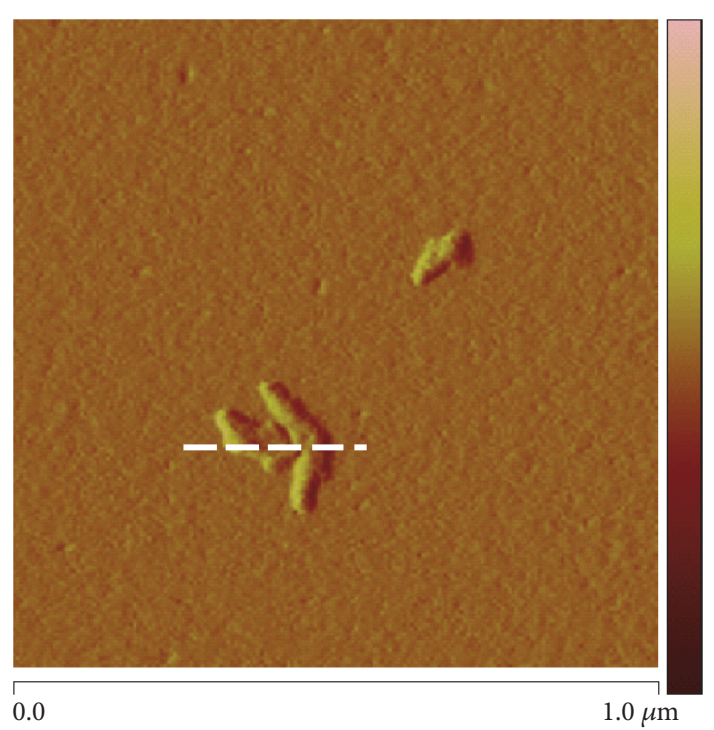

(b)

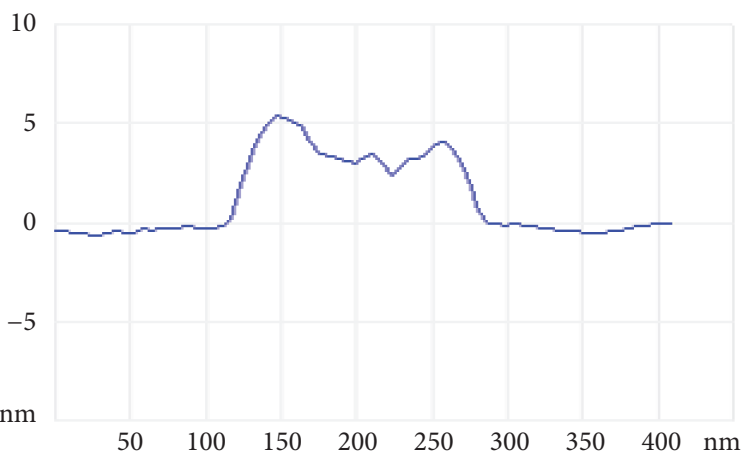

(d)

Figure 2: Representative tapping mode AFM deflection image of (a) non-sonicated GO NPs and (b) sonicated GO NPs. (c and d) The corresponding height profiles along the dashed lines in aand $\mathrm{b}$, showing the height levels.

pristine GO particles with concentrations of 20 and $50 \mu \mathrm{g} / \mathrm{ml}$ (Figure 6) cause a slight reduction in the number of viable attached A549 cells. Interestingly, a slight stimulation in the cell attachment was observed in the A549 cells treated with the lowest NPs concentrations -0.1 and $1 \mu \mathrm{g} / \mathrm{ml}$ in both NPs types, compared to the control cells. Cell spreading ability of A549 cells also was not affected under exposure to GO and GO- $\mathrm{NH}_{2}$ particles (Figure 7).

Using Lep3 cells to evaluate cytotoxicity of GO and GO- $\mathrm{NH}_{2}$ particles on non-tumor cells we detected that Lep3 cells were more sensitive to short-term exposure of $\mathrm{GO}$ and $\mathrm{GO}-\mathrm{NH}_{2}$ particles compared to A549 cells. Lep3 single cells and aggregates become smaller and more shrunk under exposure to GO and especially to GO- $\mathrm{NH}_{2}$ (Figure 8). Quantitative evaluation of cell viability assessed by CCK-1 assay showed that optical density (OD) values (referring to the number of viable cells) decreased at the highest concentrations of NPs (20 for GO and 20 and $50 \mu \mathrm{g} / \mathrm{ml}$ for GO$\mathrm{NH}_{2}$ ) although it was not found dose-dependent correlation between number of viable cells and concentrations of NPs (Figure 9).
3.2.2. Long-Term Cytotoxicity. The cell proliferation rate is an important indicator of the NPs cytotoxic potential. Thus, to understand better the cytotoxic effect of GO and GO$\mathrm{NH}_{2}$ particles on A549 and Lep3 cells we have studied the alteration in cell proliferation/metabolic ability after a longer exposure. We have used CCK- 8 assay, a standard in vitro test for determination of NPs toxicity especially of graphene materials, because WST- 8 reagent was found not to react with graphene materials [40]. The results obtained revealed that $\mathrm{GO}$ and $\mathrm{GO}-\mathrm{NH}_{2}$ particles caused a dose-dependent decrease in proliferation rate of A549 cells (Figure 10) at the 48th hour. Compared to the control untreated cells, optical density (OD) values in treated A549 cells were significantly decreased. A linear correlation was identified between the concentration of pristine GO particles and measured OD values in A549 cells whereas the lowest concentrations of aminated GO NPs $(0.1$ and $1 \mu \mathrm{g} / \mathrm{ml})$ resulted in insignificant $(\mathrm{p}>0.5)$ decrease of cell proliferation rates. The higher concentrations of GO- $\mathrm{NH}_{2}$ particles $(10,20$, and $50 \mu \mathrm{g} / \mathrm{ml})$ however impaired even stronger than pristine GO the proliferation ability of A549 cells. The measured OD values after the 


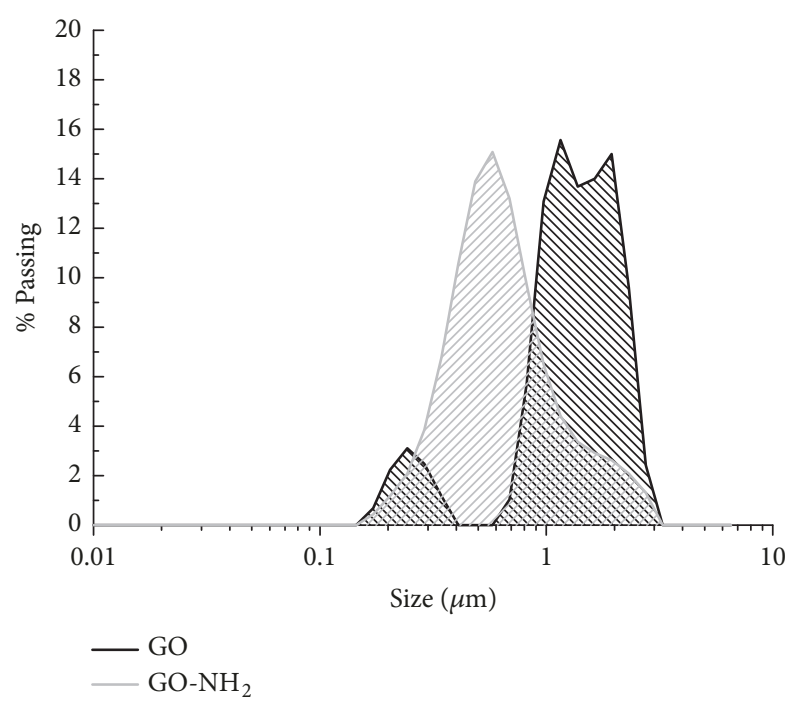

FIgURE 3: Pristine GO and GO- $\mathrm{NH}_{2}$ nanoparticles size distribution.

treatment with $10 \mu \mathrm{g} / \mathrm{ml} \mathrm{GO}-\mathrm{NH}_{2}$ were almost 2-fold lower than that of the control cells, while for the pristine GO at this concentration the decrease in the cell number was less than 1 -fold. The same trend was observed at 20 and $50 \mu \mathrm{g} / \mathrm{ml}$ as at the highest concentration the number of cells was reduced more than 3.5 folds compared to the to control cells ( 0.93 and 0.87 for $\mathrm{GO}$ and $\mathrm{GO}-\mathrm{NH}_{2}$ respectively, vs 3.12 and 3.09 for the control).

In contrast, in non-tumor Lep3 cells proliferation ability which was not affected at all concentrations of both types of NPs confirmed our previous observations with DND particles that cytotoxicity of nanomaterials is critically dependent on the cell type. No apparent differences were observed in cells treated with GO or GO- $\mathrm{NH}_{2}$ particles (Figure 10, lower panel).

\section{Discussion}

One of the first steps in investigations of a potential anticancer agent is the evaluation of its in vitro toxicity towards tumor and normal cells [41]. Therefore, in the present work we aimed to study several aspects of the potential cytotoxic effect of pristine and ammonia-modified GO nanoparticles on a tumor cell line A549 and non-tumor embryonic Lep3 cells. The results from the short-term exposure of cells to NPs in general revealed a slight cytotoxic effect of both NPs at the highest concentrations $(20$ and $50 \mu \mathrm{g} / \mathrm{ml})$ on tumor cells and a stronger effect on non-tumor cells, as the toxic effect of GO- $\mathrm{NH}_{2}$ was more pronounced. Our results obtained for $\mathrm{GO}$ are rather in agreement with the results published by Chang et al. who did not find any negative effects of GO on A549 morphology and proliferation after 24 hours incubation [7]. Also, the observed slight increase in the number of the attached cells at the lower concentrations of NPs ( 0.1 and 1 $\mu \mathrm{g} / \mathrm{ml}$ ) could be explained with a possible hormesis effect, which is stimulation of cell viability induced by low doses of potentially toxic agents. At low doses GO NPs (pristine and ammonia-modified) displayed hormesis effect by improving cell attachment and viability. Such effect induced by silver NPs was recently demonstrated on human hepatoma cells by Jiao et al. [42]. In a longer incubation for $48 \mathrm{~h}$ a very clear dose-dependent cytotoxic effect of GO and especially of GO$\mathrm{NH}_{2}$ NPs on proliferation ability of A549 cells was observed. On the contrary, long-term exposure of embryonic stem cells to GO particles did not affect their proliferation ability. This suggests that the pathways through which the nanoparticles affect the tumor cells are time-consuming unlike embryonic stem cells. Thus, comparing tumor and non-tumor cells we could conclude that Lep3 cells were more sensitive than A549 cells to the short-term exposure of NPs (pristine and ammonia-modifed GO) while at $48 \mathrm{~h}$ A549 cells were more sensitive than embryonic stem cells suggesting a cell-specific toxicity response.

In most of the performed experiments the cytotoxic effect of the ammonia-modified GO was stronger than that of the pristine GO which could be referred not only to chemical but also to the physical properties of the NPs. The size of the particles is one of the most important parameters that could seriously affect their interactions with cells [43]. However, there are still controversies regarding the association between the size and the toxicity of the particles. Some papers have demonstrated that the exposure to greater size particles $(100 \mathrm{~nm})$ can cause more adverse biological effects than the smaller ones $(10 \mathrm{~nm})$ [44]. Other authors have reported the contrary: a stronger cytotoxicity induced by nanoparticles with smaller dimensions $[45,46]$. In our previous study on detonation nanodiamond (DND) particles we found that smaller sized DND particles are more toxic for osteosarcoma MG-63 cells and primary rat mesenchymal stem cells [34]. The results from the present work also demonstrated that smaller sized NPs $\left(\mathrm{GO}-\mathrm{NH}_{2}\right)$ suppressed in a greater degree the proliferation of lung cancer A549 cells than pristine GO with prevailing size in microscale but from the other hand did not affect proliferation of embryonic Lep3 cells.

Zeta potential of NPs is another important factor that could influence particle cytotoxicity. Positive zeta potential of NPs has been shown to increase the internalization of polymeric nanoparticles in A549 and other non-phagocytic cells [47]. Slowing and coworkers demonstrated that the surface-functionalization of mesoporous silica nanoparticles with amino groups resulted in a specific receptor-mediated endocytosis by the cancer Hela cells [38]. In addition there is evidence that the positively charged NPs could be more promising drug carriers as they are more resistant than the negatively charged ones to the opsonization and clearance by the macrophages in the blood stream of the patient [48]. Therefore, we speculate that the combination of smaller size and positive zeta potential of $\mathrm{GO}-\mathrm{NH}_{2}$ makes NPs able to interact more effectively with the cancer cells resulting in suppression of their main vital functions and reducing the number of living tumor cells. Moreover the studies of Singh et al. and Li et al. $[18,28]$ in combination with our results for Lep3 suggest that amine-modified nanomaterials demonstrate lower affinity towards more sensitive cells like neurons, platelets, and embryonic stem cells which is an additional reason to consider these materials as potential candidates for anticancer therapeutic agents. 


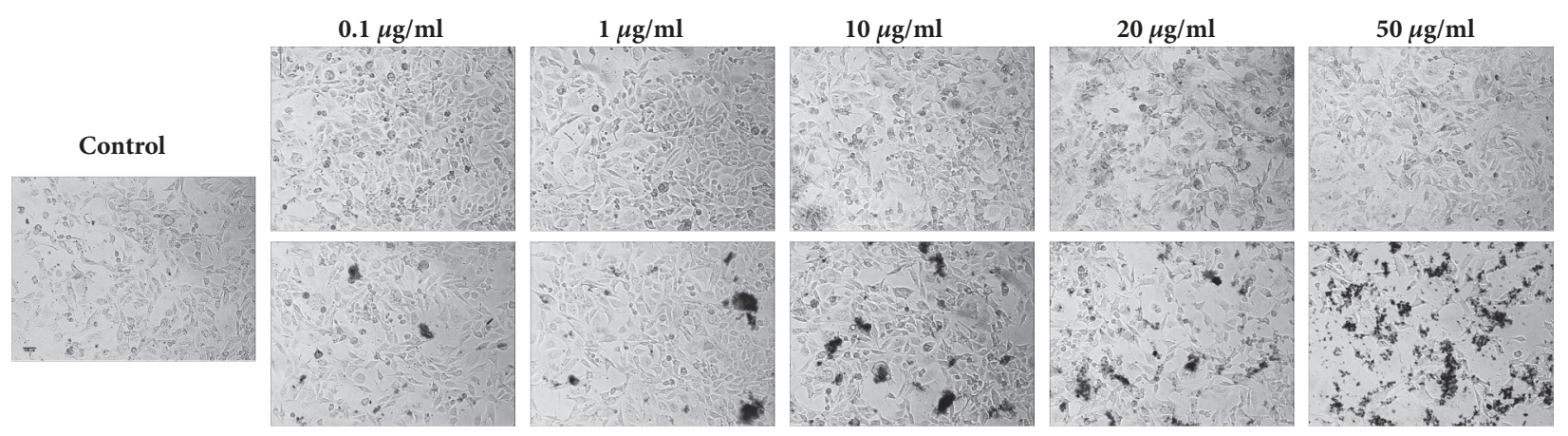

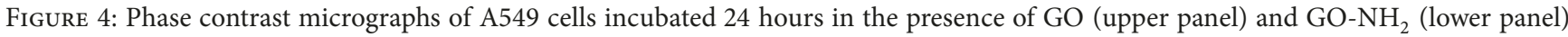
nanoparticles at different concentrations. Magnification 10x.
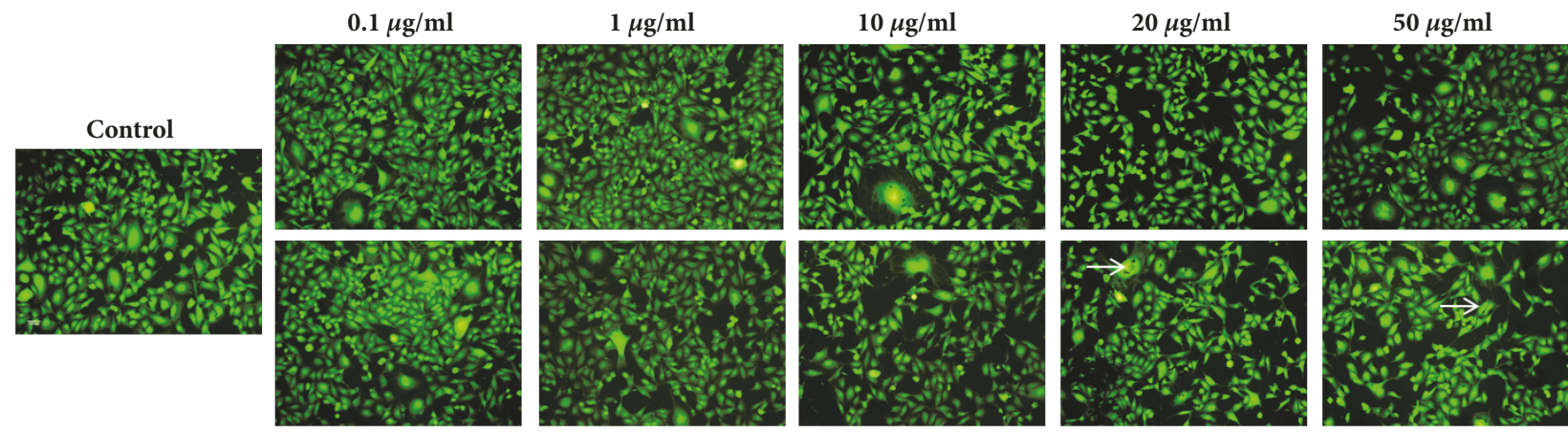

FIGURE 5: Fluorescent micrographs of FDA-stained A549 cells incubated 24 hours in the presence of GO (upper panel) and GO-NH${ }_{2}(\mathrm{lower}$ panel) nanoparticles at different concentrations. Magnification 10x.

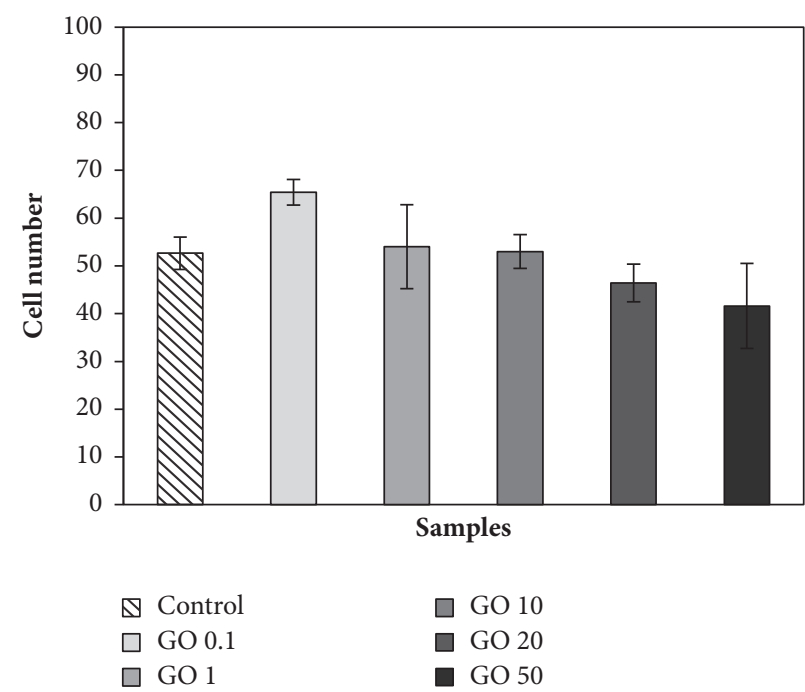

(a)

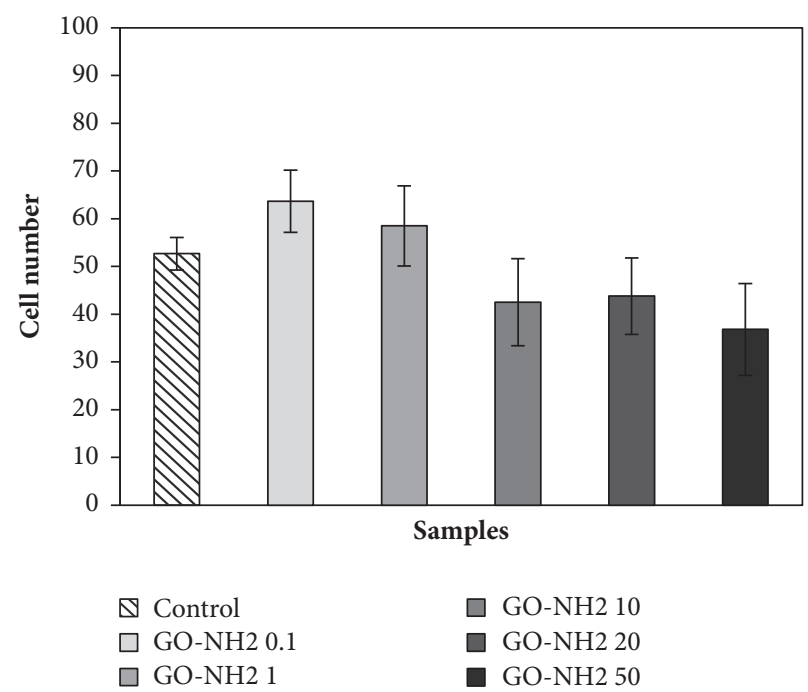

(b)

Figure 6: Number of viable A549 cells after 24 hours incubation in the presence of (a) GO and (b) GO- $\mathrm{NH}_{2}$.

\section{Conclusions}

In the present study a cytotoxicity comparison between pristine GO and ammonia modified GO has been performed. In general, both particles produced time- and concentrationdependent changes in cellular morphology, viability, and proliferation ability, although there are some notable differences. We found that ammonia-modified GO particles have more pronounced tendency to form aggregates and are more toxic than pristine GO in both cell types, tumor lung A549 cells, and non-tumor, embryonic Lep3 cells. GO-NH significantly impaired the proliferation activity of A549 cells 

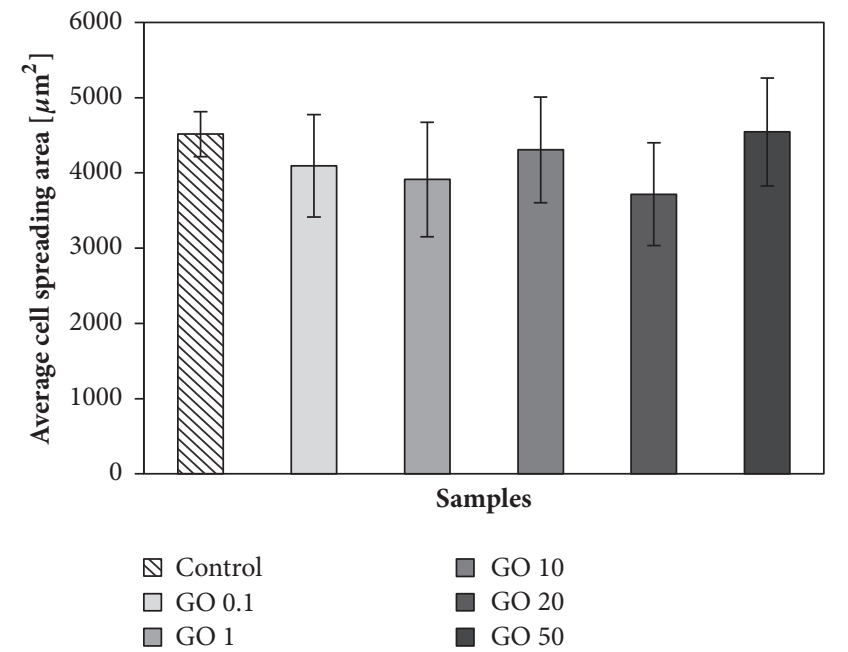

(a)
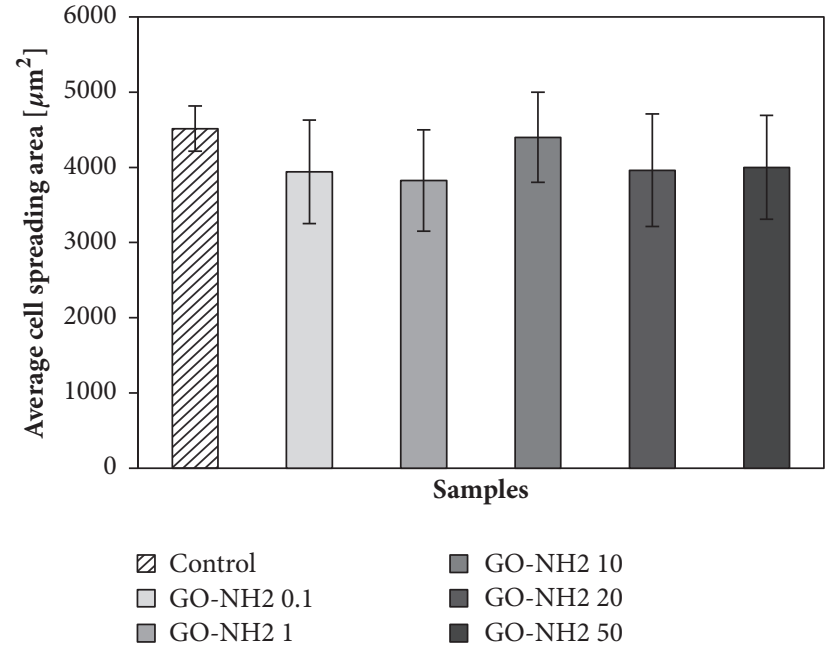

(b)

FIGURE 7: Average cell spreading area of A549 cells after 24 hours incubation in the presence of (a) GO and (b) GO-NH 2.
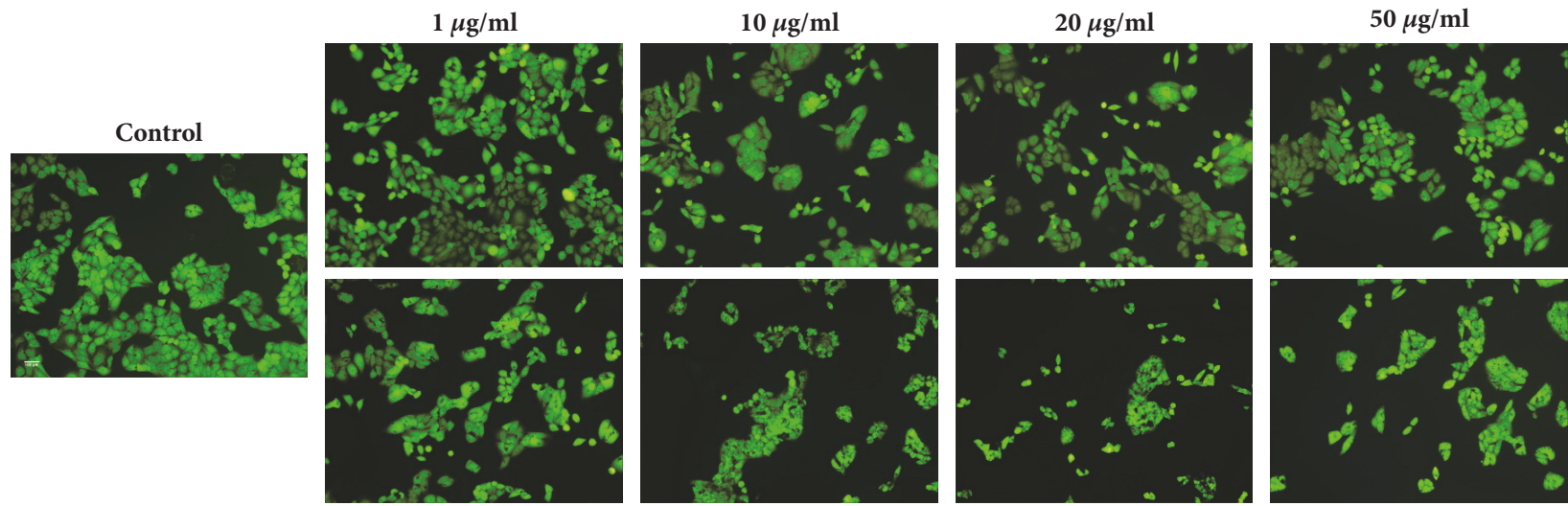

FIGURE 8: Fluorescent micrographs of FDA-stained Lep3 cells incubated 24 hours in the presence of GO (upper panel) and GO-NH ${ }_{2}$ (lower panel) nanoparticles at different concentrations. Magnification 10x.
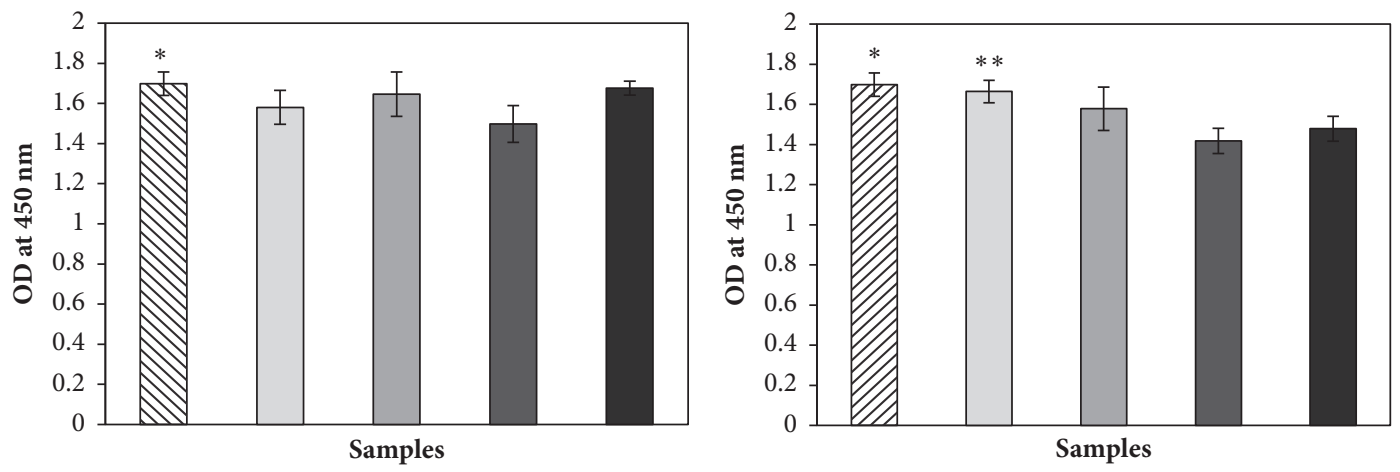

$$
\begin{aligned}
& \square \text { Control } \\
& \square \text { GO } 1 \\
& \square \text { GO } 10 \\
& \square \text { GO } 20 \\
& \square \text { GO } 50
\end{aligned}
$$
$\square$ Control
$\square$ GO-NH2 1
$\square \mathrm{GO}-\mathrm{NH} 210$
GO-NH2 20
- GO-NH2 50

(a)

(b)

Figure 9: Viability of Lep3 cells after 24 hours incubation in the presence of (a) GO and (b) GO-NH 


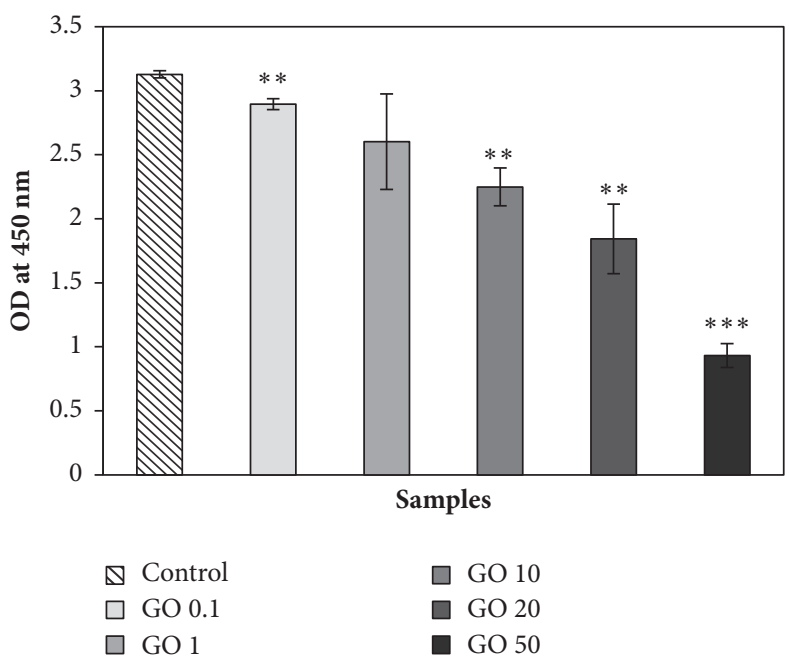

(a)

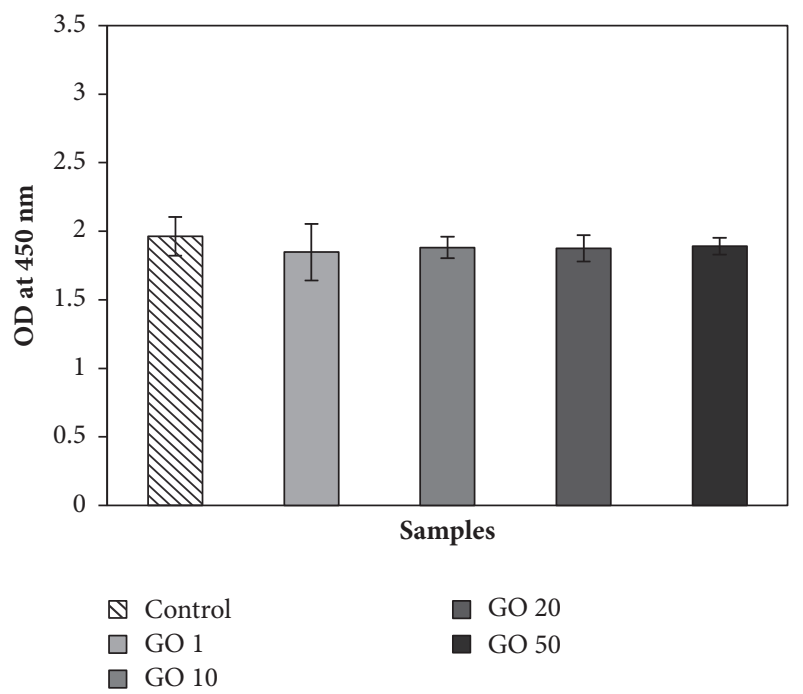

(c)

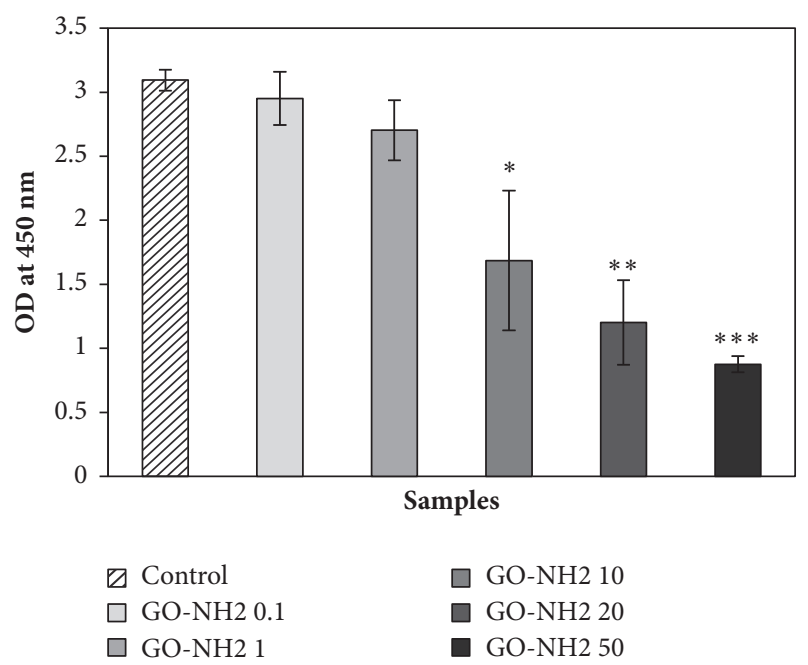

(b)

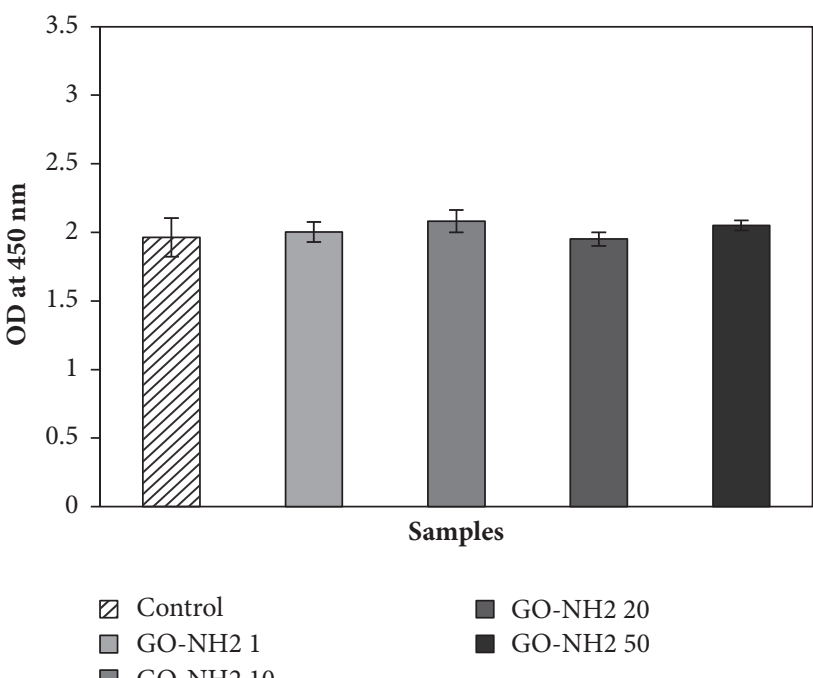

(d)

FIGURE 10: Proliferation activity of the two cell types after 48 hours incubation in the presence of the nanoparticles: A549 cells incubated with (a) GO and (b) GO-NH

at concentrations of $10-50 \mu \mathrm{g} / \mathrm{ml}$ as well as the number of viable A549 and Lep3 cells and the morphology of embryonic Lep3 cells. Both NPs (pristine and ammonia-modified GO nanoparticles) applied in small doses for a short period did not alter significantly the viability of lung cancer A549 cells but affected embryonic stem cells. Comparing tumor and non-tumor cells we found that after short-term exposure to NPs the embryonic cells were more sensitive while at longterm exposure, the more sensitive were the lung cancer cells pointing a cell specific effect of $\mathrm{GO}$ and $\mathrm{GO}-\mathrm{NH}_{2}$ particles.

\section{Data Availability}

The data used to support the findings of this study are available from the corresponding author upon request.

\section{Conflicts of Interest}

The authors declare that there are no conflicts of interest regarding the publication of this paper.

\section{Acknowledgments}

This work was supported by a bilateral project, BulgariaChina [Grant no. DNTS/ 01/6/2016].

\section{References}

[1] J. Lee, J. Kim, S. Kim, and D.-H. Min, "Biosensors based on graphene oxide and its biomedical application," Advanced Drug Delivery Reviews, vol. 105, pp. 275-287, 2016. 
[2] S. Gurunathan and J.-H. Kim, "Synthesis, toxicity, biocompatibility, and biomedical applications of graphene and graphenerelated materials," International Journal of Nanomedicine, vol. 11, pp. 1927-1945, 2016.

[3] X. Sun, Z. Liu, K. Welsher et al., "Nano-graphene oxide for cellular imaging and drug delivery," Nano Research, vol. 1, no. 3, pp. 203-212, 2008.

[4] X. Y. Yang, X. Y. Zhang, Z. F. Liu, Y. Ma, Y. Huang, and Y. Chen, "High-efficiency loading and controlled release of doxorubicin hydrochloride on graphene oxide," The Journal of Physical Chemistry C, vol. 112, no. 45, pp. 17554-17558, 2008.

[5] L. M. Zhang, J. G. Xia, Q. H. Zhao, L. Liu, and Z. Zhang, "Functional graphene oxide as a nanocarrier for controlled loading and targeted delivery of mixed anticancer drugs," Small, vol. 6, no. 4, pp. 537-544, 2010.

[6] G. Chauhan, V. Chopra, A. Tyagi, G. Rath, R. K. Sharma, and A. K. Goyal, "“Gold nanoparticles composite-folic acid conjugated graphene oxide nanohybrids" for targeted chemothermal cancer ablation: In vitro screening and in vivo studies," European Journal of Pharmaceutical Sciences, vol. 96, pp. 351361, 2017.

[7] Y. Chang, S. T. Yang, J. H. Liu et al., "In vitro toxicity evaluation of graphene oxide on A549 cells," Toxicology Letters, vol. 200, pp. 201-210, 2011.

[8] L. Yan, Z. Gu, and Y. Zhao, "Chemical mechanisms of the toxicological properties of nanomaterials: Generation of intracellular reactive oxygen species," Chemistry - An Asian Journal, vol. 8, no. 10, pp. 2342-2353, 2013.

[9] L. de Marzi, L. Ottaviano, F. Perrozzi et al., "Flake size-dependent cyto and genotoxic evaluation of graphene oxide on in vitro A549, CaCo2 and vero cell lines," Journal of Biological Regulators \& Homeostatic Agents, vol. 28, no. 2, pp. 281-289, 2014.

[10] J. Kydd, R. Jadia, P. Velpurisiva, A. Gad, S. Paliwal, and P. Rai, "Targeting strategies for the combination treatment of cancer using drug delivery systems," Pharmaceutics, vol. 9, no. 4, 2017.

[11] H. Yue, W. Wei, Z. Yue et al., "The role of the lateral dimension of graphene oxide in the regulation of cellular responses," Biomaterials, vol. 33, no. 16, pp. 4013-4021, 2012.

[12] K. Yang, H. Gong, X. Shi, J. Wan, Y. Zhang, and Z. Liu, "In vivo biodistribution and toxicology of functionalized nanographene oxide in mice after oral and intraperitoneal administration," Biomaterials, vol. 34, no. 11, pp. 2787-2795, 2013.

[13] L. Ou, B. Song, H. Liang et al., "Toxicity of graphene-family nanoparticles: A general review of the origins and mechanisms," Particle and Fibre Toxicology, vol. 13, no. 1, pp. 57-81, 2016.

[14] Kenry, "Understanding the hemotoxicity of graphene nanomaterials through their interactions with blood proteins and cells," Journal of Materials Research, pp. 1-14, 2017.

[15] S. Li, Z. Peng, X. Han, and R. M. Leblanc, "Interactions between Graphene Oxide and Biomolecules from Surface Chemistry and Spectroscopy," in Recent Progress in Colloid and Surface Chemistry with Biological Applications, vol. 1215 of ACS Symposium Series, pp. 43-64, American Chemical Society, Washington, DC, USA, 2015.

[16] S. K. Singh, M. K. Singh, M. K. Nayak et al., "Thrombus inducing property of atomically thin graphene oxide sheets," ACS Nano, vol. 5, no. 6, pp. 4987-4996, 2011.

[17] S. K. Singh, M. K. Singh, M. K. Nayak, S. Kumari, J. J. A. Grácio, and D. Dash, "Size distribution analysis and physical/fluorescence characterization of graphene oxide sheets by flow cytometry," Carbon, vol. 49, no. 2, pp. 684-692, 2011.
[18] S. K. Singh, M. K. Singh, P. P. Kulkarni, V. K. Sonkar, J. J. A. Grácio, and D. Dash, "Amine-modified graphene: Thromboprotective safer alternative to graphene oxide for biomedical applications," ACS Nano, vol. 6, no. 3, pp. 2731-2740, 2012.

[19] A. Jarosz, M. Skoda, I. Dudek et al., "Oxidative stress and mitochondrial activation as the main mechanisms underlying graphene toxicity against human cancer cells," Oxidative Medicine and Cellular Longevity, vol. 2016, Article ID 5851035, 14 pages, 2016.

[20] P. Aggarwal, J. B. Hall, C. B. McLeland, M. A. Dobrovolskaia, and S. E. McNeil, "Nanoparticle interaction with plasma proteins as it relates to particle biodistribution, biocompatibility and therapeutic efficacy," Advanced Drug Delivery Reviews, vol. 61, no. 6, pp. 428-437, 2009.

[21] L. Feng and Z. Liu, "Graphene in biomedicine: Opportunities and challenges," Nanomedicine, vol. 6, no. 2, pp. 317-324, 2011.

[22] K. Knop, R. Hoogenboom, D. Fischer, and U. S. Schubert, "Poly(ethylene glycol) in drug delivery: pros and cons as well as potential alternatives," Angewandte Chemie International Edition, vol. 49, no. 36, pp. 6288-6308, 2010.

[23] W. Yang, S. Liu, T. Bai et al., "Poly(carboxybetaine) nanomaterials enable long circulation and prevent polymer-specific antibody production," Nano Today, vol. 9, no. 1, pp. 10-16, 2014.

[24] S. Kontos and J. A. Hubbell, "Drug development: Longer-lived proteins," Chemical Society Reviews, vol. 41, no. 7, pp. 26862695, 2012.

[25] S. Y. Wu, S. S. An, and J. Hulme, "Current applications of graphene oxide in nanomedicine," International Journal of Nanomedicine, vol. 10, pp. 9-24, 2015.

[26] L. Štrbková, A. Manakhov, L. Zajíčková, A. Stoica, P. Veselý, and R. Chmelík, "The adhesion of normal human dermal fibroblasts to the cyclopropylamine plasma polymers studied by holographic microscopy," Surface and Coatings Technology, vol. 295, pp. 70-77, 2016.

[27] J. H. Lee, H. W. Jung, I.-K. Kang, and H. B. Lee, "Cell behaviour on polymer surfaces with different functional groups," Biomaterials, vol. 15, no. 9, pp. 705-711, 1994.

[28] H.-L. Li, H. Zhang, H. Huang et al., "The effect of amino density on the attachment, migration, and differentiation of rat neural stem cells in Vitro," Molecules and Cells, vol. 35, no. 5, pp. 436443, 2013.

[29] P. Amornsudthiwat, R. Mongkolnavin, S. Kanokpanont, J. Panpranot, C. S. Wong, and S. Damrongsakkul, "Improvement of early cell adhesion on Thai silk fibroin surface by low energy plasma," Colloids and Surfaces B: Biointerfaces, vol. 111, pp. 579586, 2013.

[30] H. J. Lee, J. Park, O. J. Yoon et al., "Amine-modified singlewalled carbon nanotubes protect neurons from injury in a rat stroke model," Nature Nanotechnology, vol. 6, no. 2, pp. 121-125, 2011.

[31] J. R. Molina, P. Yang, S. D. Cassivi, S. E. Schild, and A. A. Adjei, "Non-small cell lung cancer: epidemiology, risk factors, treatment, and survivorship," Mayo Clinic Proceedings, vol. 83, no. 5, pp. 584-594, 2008.

[32] X. Zhang, J. Yin, C. Peng et al., "Distribution and biocompatibility studies of graphene oxide in mice after intravenous administration," Carbon, vol. 49, no. 3, pp. 986-995, 2011.

[33] J. Gregory, Particles in Water, CRC Press, Boca Raton, 1st edition, 2005.

[34] M. Keremidarska, A. Ganeva, D. Mitev et al., "Comparative study of cytotoxicity of detonation nanodiamond particles with 
an osteosarcoma cell line and primary mesenchymal stem cells," Biotechnology \& Biotechnological Equipment, vol. 28, no. 4, pp. 733-739, 2014.

[35] S. Stankovich, D. A. Dikin, R. D. Piner et al., "Synthesis of graphene-based nanosheets via chemical reduction of exfoliated graphite oxide," Carbon, vol. 45, no. 7, pp. 1558-1565, 2007.

[36] H. Begum, M. S. Ahmed, and S. Jeon, "New approach for porous chitosan-graphene matrix preparation through enhanced amidation for synergic detection of dopamine and uric acid," ACS Omega, vol. 2, no. 6, pp. 3043-3054, 2017.

[37] B. Wang, B. Luo, M. Liang et al., "Chemical amination of graphene oxides and their extraordinary properties in the detection of lead ions," Nanoscale, vol. 3, no. 12, pp. 5059-5066, 2011.

[38] I. Slowing, B. G. Trewyn, and V. S. Y. Lin, "Effect of surface functionalization of MCM-41-type mesoporous silica nanoparticles on the endocytosis by human cancer cells," Journal of the American Chemical Society, vol. 128, no. 46, pp. 14792-14793, 2006.

[39] M. K. Alqadi, O. A. Abo Noqtah, F. Y. Alzoubi, J. Alzouby, and K. Aljarrah, "PH effect on the aggregation of silver nanoparticles synthesized by chemical reduction," Materials Science-Poland, vol. 32, no. 1, pp. 107-111, 2014.

[40] S. Gurunathan, J. W. Han, V. Eppakayala, and J.-H. Kim, "Green synthesis of graphene and its cytotoxic effects in human breast cancer cells," International Journal of Nanomedicine, vol. 8, pp. 1015-1027, 2013.

[41] M. López-Lázaro, “Two preclinical tests to evaluate anticancer activity and to help validate drug candidates for clinical trials," Oncoscience, vol. 2, no. 2, pp. 91-98, 2015.

[42] Z.-H. Jiao, M. Li, Y.-X. Feng, J.-C. Shi, J. Zhang, and B. Shao, "Hormesis effects of silver nanoparticles at non-cytotoxic doses to human hepatoma cells," PLoS ONE, vol. 9, no. 7, Article ID e102564, 2014.

[43] M. Akter, M. T. Sikder, M. M. Rahman et al., "A systematic review on silver nanoparticles-induced cytotoxicity: Physicochemical properties and perspectives," Journal of Advanced Research, vol. 9, pp. 1-16, 2018.

[44] T. A. J. Souza, L. P. Franchi, L. R. Rosa, M. A. M. S. da Veiga, and C. S. Takahashi, "Cytotoxicity and genotoxicity of silver nanoparticles of different sizes in CHO-K1 and CHO-XRS5 cell lines," Mutation Research - Genetic Toxicology and Environmental Mutagenesis, vol. 795, pp. 70-83, 2016.

[45] S. S. O. Zaki, M. N. Ibrahim, and H. Katas, "Particle size affects concentration-dependent cytotoxicity of chitosan nanoparticles towards mouse hematopoietic stem cells," Journal of Nanotechnology, vol. 2015, Article ID 919658, 5 pages, 2015.

[46] Devashr Sahu I, G. M. Kannan, Mukul Tailang, and R. Vijayaraghavan, "In Vitro cytotoxicity of nanoparticles: A comparison between particle size and cell type," Journal of Nanoscience, vol. 2016, Article ID 4023852, 9 pages, 2016.

[47] C. He, Y. Hu, L. Yin, C. Tang, and C. Yin, "Effects of particle size and surface charge on cellular uptake and biodistribution of polymeric nanoparticles," Biomaterials, vol. 31, no. 13, pp. 36573666, 2010.

[48] S. Honary and F. Zahir, "Effect of zeta potential on the properties of nano-drug delivery systems-a review (Part 2)," Tropical Journal of Pharmaceutical Research, vol. 12, no. 2, pp. 265-273, 2013. 

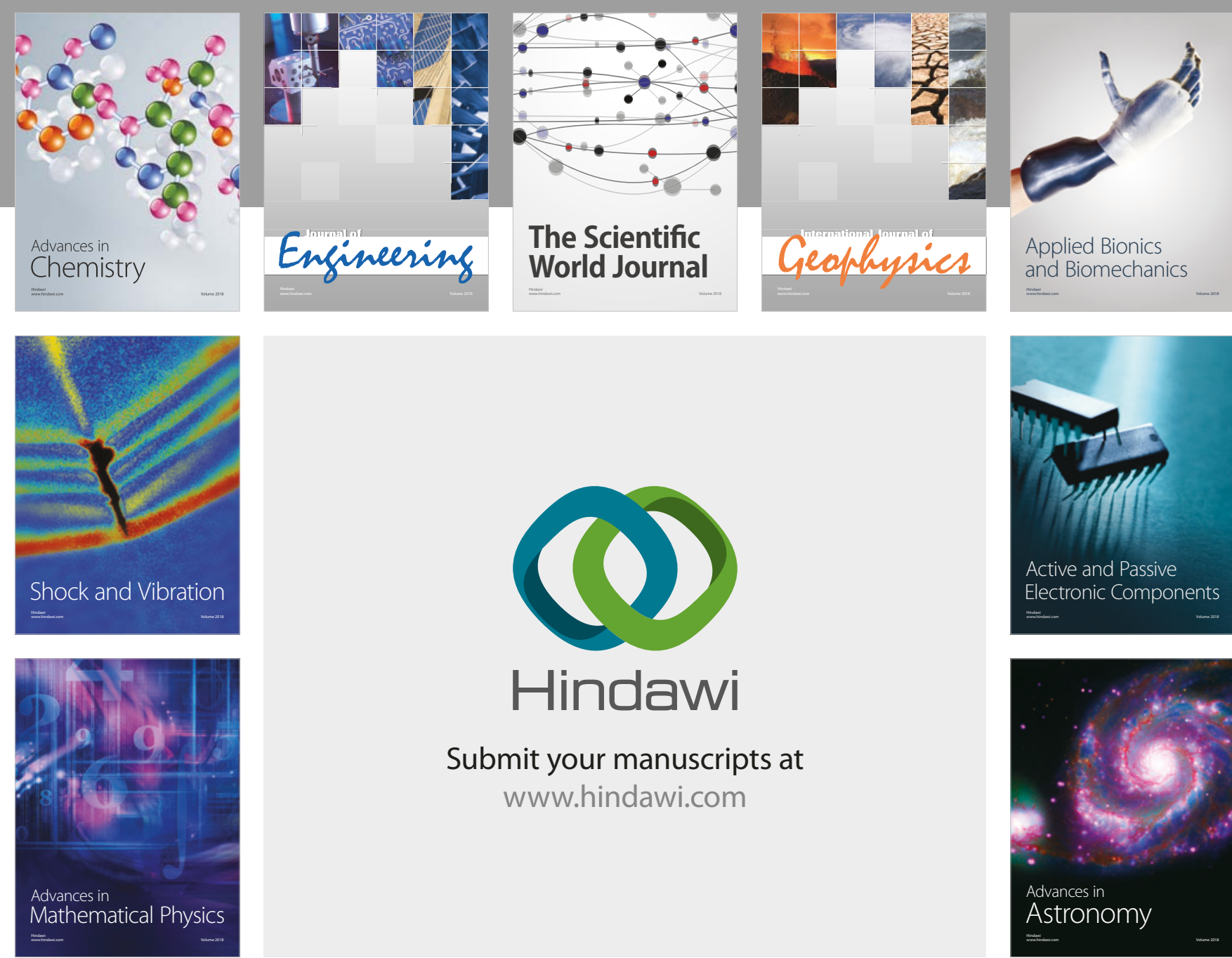

Submit your manuscripts at

www.hindawi.com

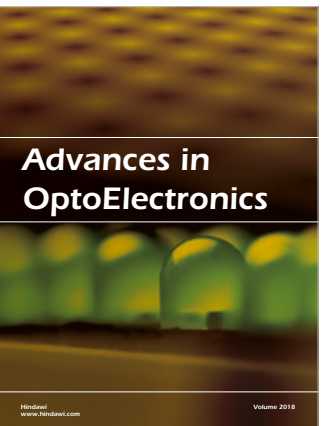

\section{Rotcting Machinery}
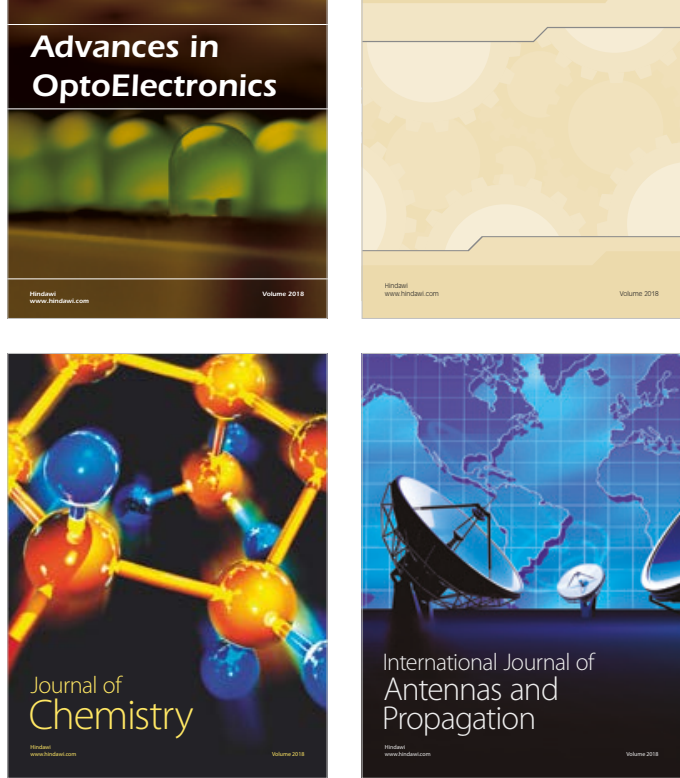

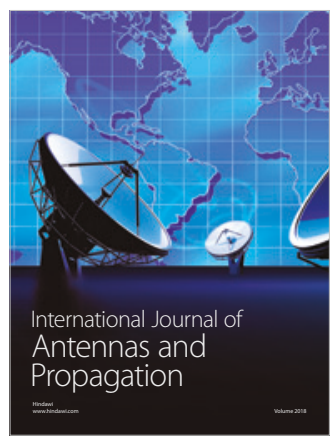

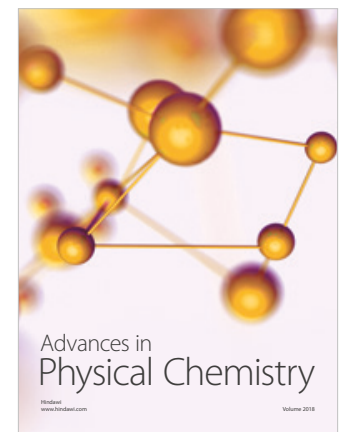

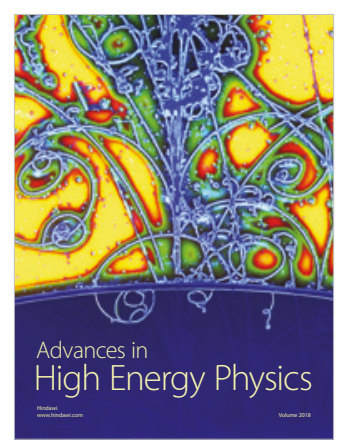

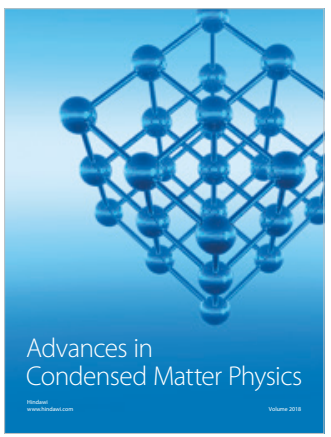

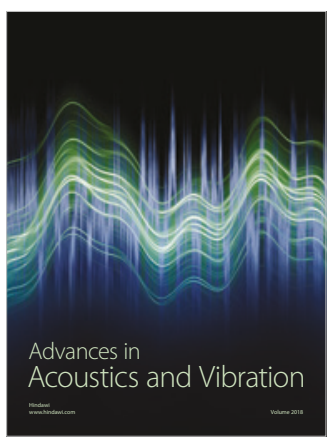

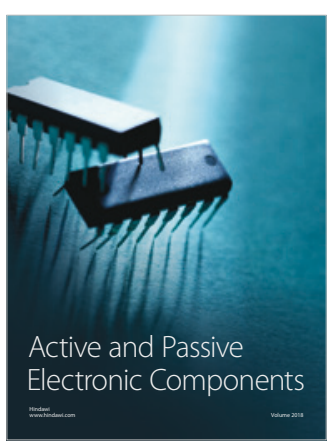
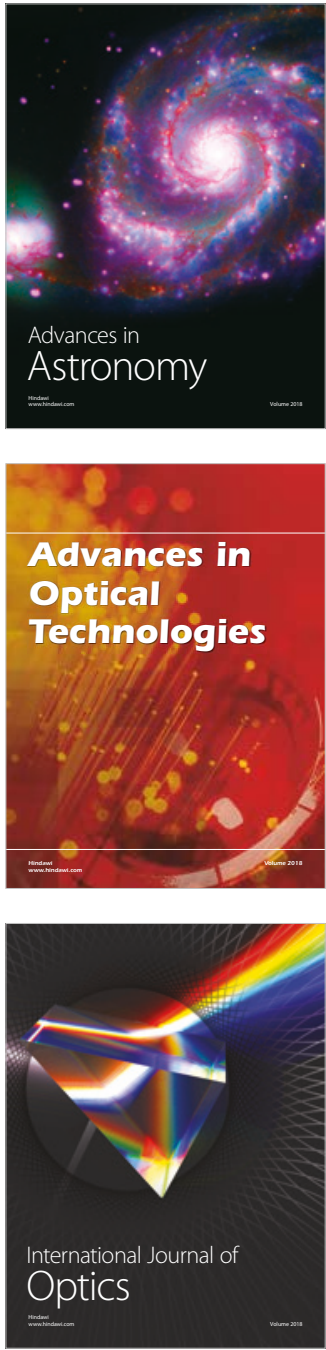